\title{
Research on Soil Resources of the NorthWest Part of the Cracau-Bistrita Depresion for Sustainable Agriculture
}

\author{
ANCA-LUIZA STANILA ${ }^{1 *}$, CATALIN CRISTIAN SIMOTA ${ }^{1}$, MIHAIL DUMITRU ${ }^{1}$, SORINA IUSTINA DUMITRU ${ }^{1}$, PETRU IGNAT ${ }^{1}$ \\ National Research Institute for Soil Science, Agrochemistry and Environment-ICPA, Bucharest, 61 Marasti Blvd., 011464, \\ Bucharest
}

\begin{abstract}
Cracau-Bistrita Depression it belongs to the investigated it is a unique physical geographical unit within Moldavian Subcarpatians, which occupies the center of the groove subcarpathic between Moldova and the Trotus Rivers. In geological terms we refer territory corresponds to a restricted part of the Moldavian Platform appears as an extension to the southwest of Russian platform. Geological rocks that are part of the northwest Cracau-Bistrita Depression parent materials generated relatively differentiated by features and nature that can be eluvial, colluvial and alluvial. After compiling size, they are made of clay and marly clay, sand, alluvial deposits. The main pedogenetic processes which led to differentiation and the formation horizons of soil the soil cover of the northwest Cracau-Bistrita Depression may be mentioned bioaccumulation, clay migration, argillisation, gleyzation and stagnogleyzation. Ensemble pedogenetic factors and pedogenetic processes specific area led to the formation of a coating on the ground floor consists of relatively varied protisols, cernisols, cambisols, luvisols, hidrisols and antrisols. Of these, the largest share is occupied by cernisols. Arable land suitability is limited by several factors, of which the most important are considered the soil, topography and drainage. So outstanding were six classes of land: from those with very good suitability for field crops, without restriction, to land that can be used only for forests as those from nearby watercourses due to flooding. Misuse of the land has led to extreme natural phenomena, considered risks that go to produce immense damage by reducing agricultural production. I particularly physical, chemical and complex risks. Most worthy of notice covers the main physical and chemical properties of soil and land degradation by destroying the soil. In order to eliminate the negative effects of limiting factors of agricultural production, reducing risk and thereby improving the productive potential of the northwest Cracau-Bistrita Depression were proposed a series of works agropedoameliorative such as regulation of water and embankment works, paper land on the contour and avoiding weeding plant cultivation on slopes, erosion control works and avoid prolonged grazing early spring or fall, ripping papers for land compacted or affected by excess moisture.
\end{abstract}

Keywords: pedogenesis, classification, morphological characteristics, physical, hydro and chemical properties, sustainable agriculture

Investigated area is located in the eastern half of the country, in the county Neamt and belongs Moldavian Subcarpathians, Cracau-Bistrita Depresion is one of the largest depressions in the relief unit [2, 23,38].

The northwest part of the Cracau-Bistrita Depression is among the regions that the diversity of the natural components ensure users obtain optimal agricultural production and income, especially if harnessed effectively, economically and environmentally existing technologies.

A productive agriculture is essential prerequisite for sustainable development of agriculture with multiple objectives, to reduce poverty and improve livelihoods, with preserving and protecting the natural resource base.

All these are not possible without special research, extensive and often lengthy.

On this importance is the territory under study dealing extensively formation, development, spread soil in the territory, morphological description of soils and the main physical, hydro and chemical, suitability natural environment for agriculture of the region and agropedoameliorative requirements [8].

Closely related to training, development and distribution of land in the territory, was intended at the outset how the appearance of each factor in the complex territory, analyzing the row structure, dynamics and function of each of them, as their role directly or indirectly in the genesis and land development.
Since the economic efficiency of agriculture is not possible without the use of all factors of landscape, I made reference to land suitability for agriculture. Thus, they considered physical properties, hydro and organic soils in all pedologic reported to the various categories of agricultural use [21].

Overlapping boundaries of this territory west of contact between geological formations of the Miocene flysch subcarpathic and oscillates between altitudes of 500-550 $\mathrm{m}$ over the entire frame mountainous north and east of Cracau meandered course and south course Bistrita.

In geographical research focus on detailed knowledge of the dynamics of the landscape. The researches carried out $[1,4,9-11]$.

Referring to researches soil and pedogeographic on depression, this has been achieved for the first time in [12]

From 1991 to undertake a series of studies and researches soil to afford new data on soil cover in this part of the country. Scientific papers that relate to soil properties from depression, have published some researchers [1820, 29, 30].

Particularly important for soil survey has spread knowledge of the main lithological units that directly influence features parent material.

Carpathian molasses deposits have undergone many changes during evolution depression under the influence 
of exogenous and biotic factors, but certain features were preserved until now.

Morphogenesis processes mobilized these formations that parent materials not conserve all their properties. Closely related to training, development and distribution of land in the territory, to supervise the occurrence of each pedogenetic factors as director indirectrole in the evolution and genesis of soils.

Overall, physical-geographical factors specific northwest part Cracau-Bistrita Depression led to the formation of a complex soil cover quite strongly differentiated from each other. Since the economic efficiency of agriculture is not possible without harnessing all environmental factors, I referred to the suitability of land for agricultural use of soil resources.

\section{Experimental part}

Materials and methods

The primary unit of basic research and mapping of soil cover was the soil profile, which allowed studying morphological characteristics of the soils and some feedback on their fertility. As a result, soils were classified based on their intrinsic properties respectively soil profile, considering horizons and diagnostic characteristics [31].

The profiles were located on the ground so as to form a network of points studied. The methods used beams parallel routes located almost equidistant to cover more or less evenlyacross the work surface, as well as the method circuit territories with rugged terrain and soil cover relatively complex, without a network paths.

Pedological mapping was performed at 1: 10.000, using topographic maps with contour lines and soil map sheet Piatra Neamt, scale 1: 200.000.

Determining the number of primary and secondary profiles is envisaged category of complexity and scale soil map. The study falls into the category of complex a-II-a and pedological mapping was performed at $1: 10.000$.

They opened 25 soil profiles depths ranging from $1-2 \mathrm{~m}$, in which soil samples were collected from numerous genetic horizons of soil, the thickness is not larger than 20 $\mathrm{cm}$.

There have been made proposals then slips samples of tests to be performed (granulometric composition, the bulk density, the permeability, the content of humus, reaction $\mathrm{pH}$, the base saturation degree, total nitrogen, phosphorus, potassium, etc.) [32].

The morphological description of soil profiles was done according to the Romanian System of Soil Taxonomy (SRTS, 2003, 2012), ICPA, Bucharest [14]. In order to establish the soils diagnosis, their morphological features have been taken into account, namely the thickness of morphological horizons, color, texture, structure, composition, adhesion, etc. Soil samples were taken from genetic horizons both in modified and unchanged settings.

In modified settings, soil samples of $20 \mathrm{~cm}$ thickness were taken in bags, for the chemical characterization to be carried. In natural (unchanged) settings, soil samples were taken using a metal cylinder of known volume (200 $\mathrm{cm}^{3}$ ), to characterize the physical and hydro-physical features, as well as the momentary soil moisture.

The analytical methods used for determination of physical, hydro-physical and chemical

Particle size analysis (granulometry)

- pipette method for fractions $<0.002 \mathrm{~mm}$, including;

- wet sieving method for fractions from 0.002 to $0.2 \mathrm{~mm}$ and dried sieving method for fractions $>0.2 \mathrm{~mm}$.
For the the textural classes and subclasses, we used the Romanian system, according to the Methodology developed for soil studies, ICPA, 1987 [39].

Bulk density (DA) method: metal cylinder of known volume $\left(200 \mathrm{~cm}^{3}\right)$ for the momentary soil moisture [6] .

Total porosity $(P T)$ : by computing PT $=(1-D A / D) * 100$

The coefficient hygroscopicity (CH): drying at $105^{\circ} \mathrm{C}$ of a sample of soil moistened in advance in equilibrium with an atmosphere saturated with water vapor (in the presence of a solution of $\left.\mathrm{H}_{2} \mathrm{SO}-10 \%\right)$ - \% by weight $(\% \mathrm{~g} / \mathrm{g})$.

Withering coefficient (CO): by calculation, by multiplication with 1.5 coefficient hygroscopicity, determined by the method of modified Mitscherlich - \% by weight $(\% \mathrm{~g} / \mathrm{g})$.

CO (\%) $=0,05+0,35 \mathrm{~A}$, where:

$\mathrm{A}=$ clay content $<0,002 \mathrm{~mm}$

Total water capacity (CT): by calculation from the formula CT $=\mathrm{PT} / \mathrm{DA}, \%$ by weight.

Useful water capacity (CU) by calculation:

$\mathrm{CU}=\mathrm{CC}-\mathrm{CO}, \%$ by weight.

Field capacity (CC). This can be determined by the direct method using the platform or the estimated indirect way. On indirect way are several possibilities:

- based on texture and bulk density;

- on the basis of equivalent moisture and bulk density;

- on the basis of the suction curve (measured on samples with the alignment unchanged).

Water permeability $(K)$ is determined by several methods, one of which, in the laboratory on samples with unchanged alignment, taken in the metal cylinder, the method I.C.P.A.

Organic matter (humus) determined by volumetric method Walkley - Black wet oxidation after the change Gogoasa (Stoica et al., 1986) [36].

Total Nitrogen (Nt): Kjeldahl method disintegration $\mathrm{H}_{2} \mathrm{SO}_{4}$ at $350^{\circ} \mathrm{C}$, a catalyst of potassium sulfate and copper sulfate.

Phosphorus accessible ( $P$ mobile): method-RiehmDomingo and dosed with colorimetric molybdenum blue method after Murphy-Riley (reduction with ascorbic acid).

Potassium ( $K$ mobile) accessible: after extraction method Egner-Riehm-Domingo and determination by flame photometry.

pH: potenbiometric, determined the combined glass electrode and a calomel, in aqueous suspension the soil/ water ratio of $1 / 2,5$.

Sum of bases (SB): extraction using $0.05 \mathrm{n}$ hydrochloric acid (Kappen-Schofield- Chirita method).

The base saturation degree (V\%) and total cation exchange capacity (T me/100 g soil), by calculation.

Hydrolytic acidity (Ah me $/ 100 \mathrm{~g}$ soil) was determined by extraction with $1 \mathrm{~N}$ sodium acetate solution buffered to $p \mathrm{H}=8.3$.

Total cation exchange capacity ( $T$ me/100 g soil) was determined with the following formula: $\mathrm{T}$ ( $\mathrm{me} / 100 \mathrm{~g}$ soil) $=\mathrm{SB}+\mathrm{Ah}$

Interpretation of the results has been submitted in accordance with Methodology developing soil studies, ICPA Bucharest, 1987, provided for in current legislation on the subject $[39,40]$.

The main sources used to develop the map soil parent material from northwest Cracau-Bistrita Depression are topographical maps, scale 1:100.000 with callsigns L-3529; L-35-41; soil map, scale 1: 200.000 , sheet Piatra Neamt $[13,41]$.

To identify the boundaries of the northwest CracauBistrita Depression were consulted in addition to topographical maps, relief units developed by Badea L. and Posea Gr. (Regionalization geomorphological) and 
information on the Geography of Romania, Vol. IV, 1987 $[3,27]$.

General physical and geographical elements (river, odds elevation, localities) were taken by vectorization of topographic map.

The areas covered by different soil types were grouped in classes taken by tracing the soil map. Subsequently vectorisation using soil map legend, demarcated areas textural classes. The projection system used was 70 Stereo. System were georeferenced topographic and soil maps.

The program maps used to achieve the parent material of the soil, the soil cover, after the suitability of arable land group was ArcView GIS. Digitization geographical elements type areas of land became a subject polygon using as a working soil map, scale 1: 200.000, sheet Piatra Neamt, spatially referenced projection Stereo 70 for overlapping elements physical and geographical statements topographic map [13].

\section{Results and discussions}

Since geologically investigated area belongs Moldavian Platform which is an extension to the southwest of Russian Platform. This is made up from the Sarmatian deposits and in deep deposits Neozoic, Mesozoic and Paleozoic. Southwest platform sank well below molasse and Carpathian flysch [41].

Quaternary presence through Pleistocen, higher Pleistocen, holocen lower and upper holocen. Eegarding Pleistocene, it consists of sands, gravels and loess-like deposit, widespread on the roof of the Cracau high altitudes between 35-40 $\mathrm{m}$ and 75-90 $\mathrm{m}$ and between.

After the granulometric composition, the parent materials consisting of clays and marly clays, sands, argillaceous marly, local gravels, loess-like deposit and alluvial deposit (fig. 1).

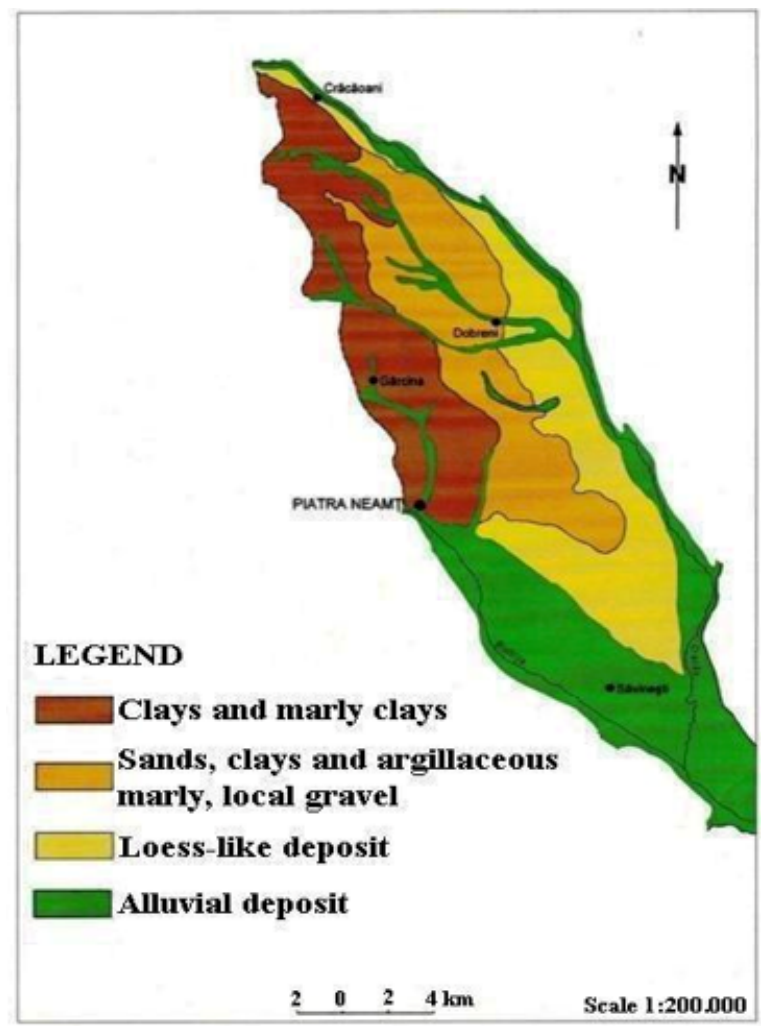

Fig. 1. Map parent material soil of the northwest Cracau-Bistrita Depression [41]
Clays and marly clays they are dominant in the western part of the basin bordered by mountain peaks of Massive Stanisoara and Gosman. Further eastward, passing for less homogeneous material, in addition to clay and marly clays on narrow ridges, some sands and gravels. On larger areas meet loess material which covers the surface of the main decking bridges, plus alluvial deposits Bistrita Floodplain and the Cracau (fig. 2) [16].

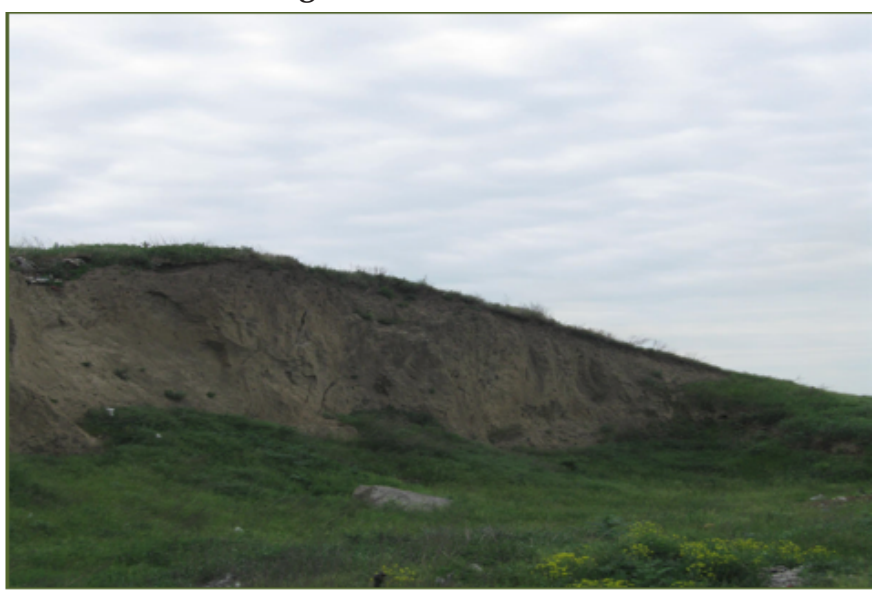

Fig. 2. Loess-like deposit terrace middle Bistrita

The thickness of these materials is quite uneven, being present at some local day gravels less run. Cracau-Bistrita is in Moldavian Subcarpathians, which occupies the central part of the groove subcarpathic between Moldova and Trotus rivers.

In the northwest basin Cracau-Bistrita differentiate two genetic types of relief namely: river denudational and fluvial [26, 27].

Relief river-denudational. Erosion processes and denudational processes they had the main role in the formation and evolution interfluves and slopes [24, 25].

In a territory development have denudational interfluve. They show in most cases a matter of rounded peaks and gently sloping plateaus. The area that we covered, peaks are generally oriented northwest-southeast, are relatively narrow and has a slope slowly falling especially for Cracau Valley (fig. 3).

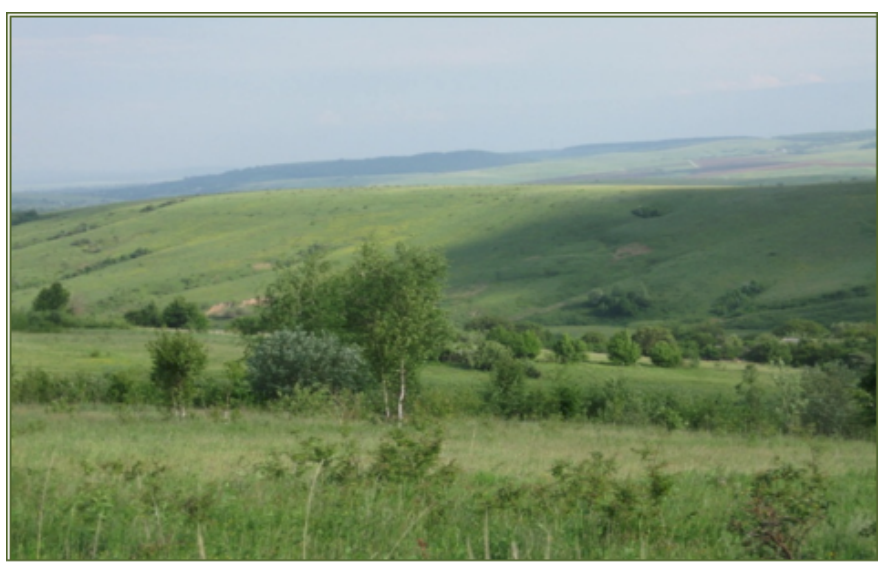

Fig. 3. Interfluves Horaita-Cracau between Poiana and Oslobeni

Relief fluvial has a considerable development in the northwest Cracau-Bistrita Depression. Thus, we can say that more than half of the study is fluvial origin, being located mainly on its east and the confluence of two rivers CracauBistrita. The relief is represented by the floodplain and terraces (fig. 4) [37].

Floodplain is the youngest relief river Holocene age. The range extension have Bistrita Floodplain and the Cracau, whose altitude varies between 1-2 m. Bistrita Floodplain widths of up to $4 \mathrm{~km}$ and it is accompanied on the left of 


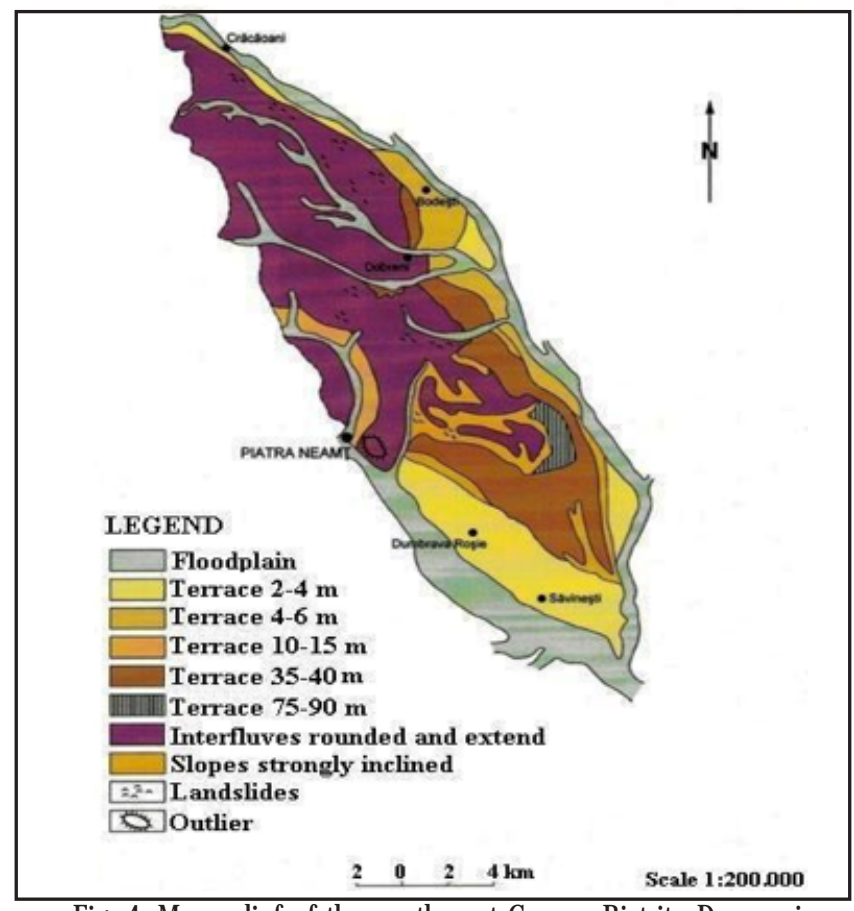

Fig. 4. Map relief of the northwest Cracau-Bistrita Depression (Posea et al., 2005) [28]

10-15 m terrace which gradually decreases to 3-4 m (at Podoleni).

The terraces have a large development in the territory. There were great many levels as follows:

- Terrace 2-4 m occurs discontinuously right left Cracau and widely developed Bistrita, where widths which can exceed $2 \mathrm{~km}$. In general, her forehead is evident downstream Savinesti.

- Terrace 4-6 $\mathrm{m}$ is present only just right Cracau from Bodesti downstream to Caciulesti.

-Terrace 10-15 $\mathrm{m}$ can be seen on the left Cuejdiu. It is located on the bridge district Darmanesti City of Piatra Neamt

-Terrace 35-40 m terrace is representative right Cracau, but may be considered terrace confluence.

- Terrace 75-90 m, the highest level meets only the right Cracau north of the town of Springs.

Among current geomorphological processes, we can mention: bed processes, accumulation processes, surface erosion, deep erosion and landslides.

Bed processes have a high intensity river Cracau as the main tributaries thereof and is reflected by the sides collapses, the formation of islands, meander, etc. These dynamic processes do notallow solidification of sediments that are constantly reshaping, regardless of the flow of rivers.

Accumulation processes is reflected by the deposit of silt in the major bed during floods and greater intensity on Cracau, Horaita and Almas.

Surface erosion affects the destruction of soil horizons and geo-morphological integrity of the slopes. Present more evident peaks interfluvial separated Horatia and Almas Valleys.

Depth erosion is present everywhere in the territory where it causes the formation of gullies, ogas and ravines (fig.5). The affected fields occur around the mountain landscape of the western end of the territory, with steep slopes, in the presence of miocene formations with a textured change.

Landslides affecting slope stability must be regarded as dynamic equilibrium processes. Towards the western end of the basin, landslides affecting all the massive hills, more preferably from the Cracau and Horaita, where spread

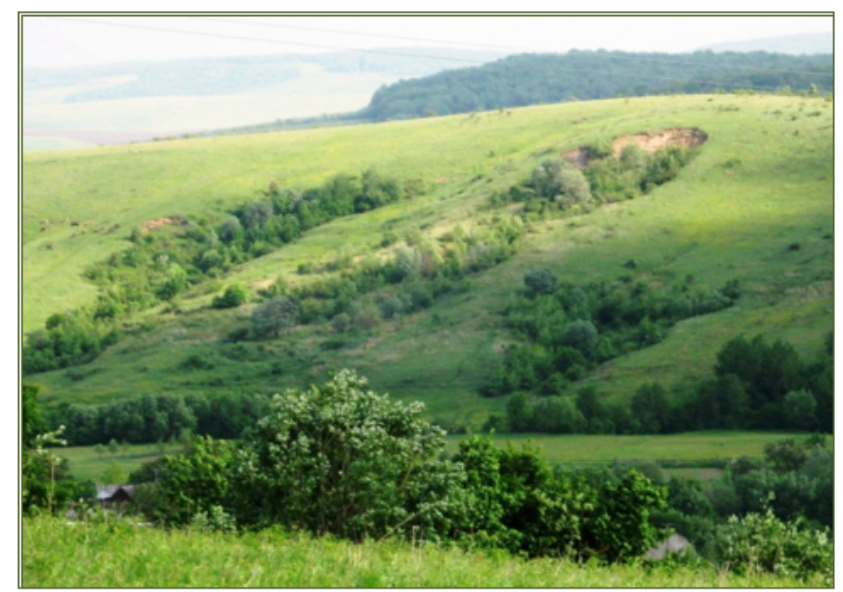

Fig. 5. Geomorphological processes slope to Oslobeni with added clays and Miocene marls and higher density of the drainage (fig. 6).

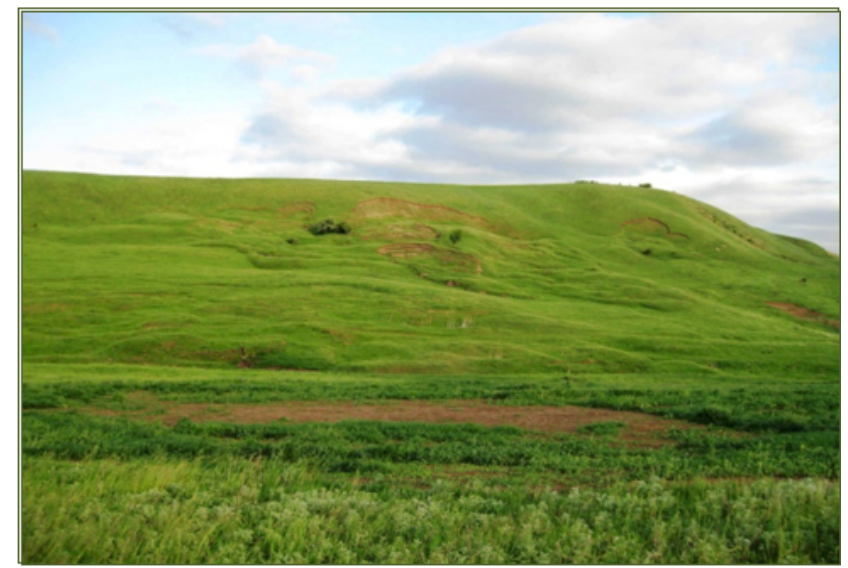

Fig.6. Landslides west of town Ciritei

Studied area is drained by rivers Bistrita and Cracau which springs in the Carpathian Mountain region, and a number of their tributaries they receive after entering the Carpathian region (fig. 7).

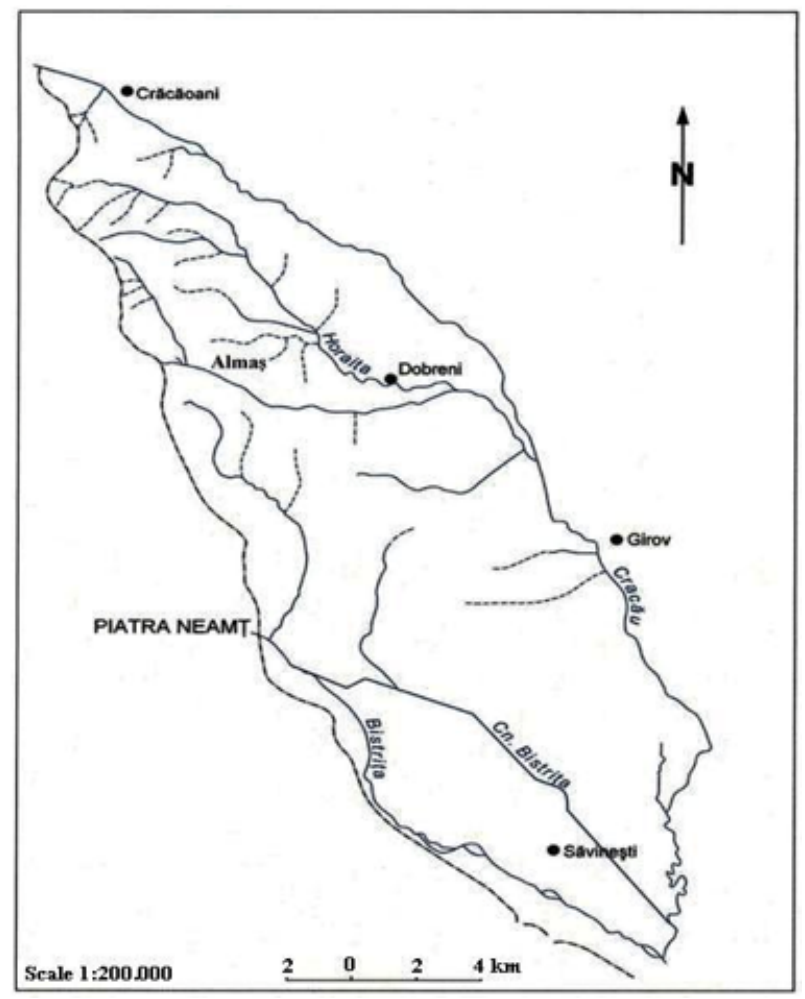

Fig. 7. Map hydrographic network of the northwest Cracau-Bistrita Depression [15] 
Bistrita River is a river in Romania flowing from Rodnei Mountains from $1850 \mathrm{~m}$ altitude, crossing the Eastern Carpathians and flows into the Siret downstream of Bacau.

Until the entry into depression, Bistrita change several times the flow direction only from Piatra Neamt downstream, it becomes northwest-southeast thereby maintaining flows into the Siret, but with a very pronounced meandering coefficient (fig. 8).

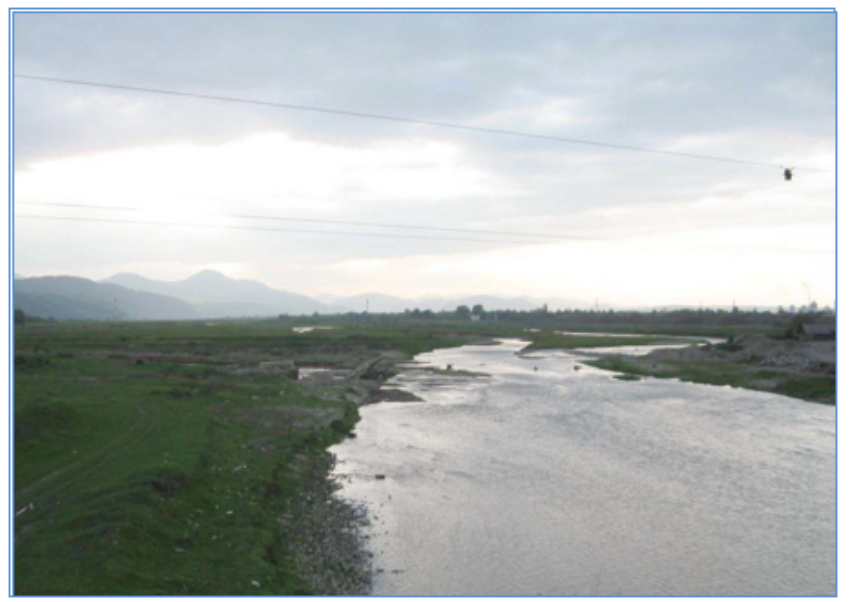

Fig. 8. River bed Bistrita in Cut locality

Cracau River springs from Stanisoara Mountains and generally follows a flow direction northwest-southeast to its mouth in Bistrita, after many meander (fig. 9).

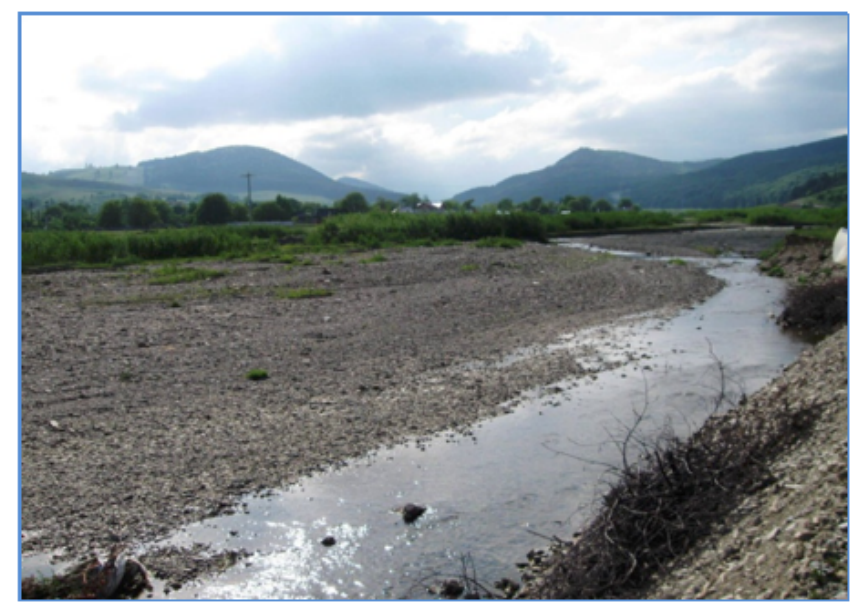

Fig. 9. Cracau River out of the mountains to Cracaoani

Northwest Bistrita-Cracau Depression belongs forest zone namely deciduous forest. Woody vegetation consists of forests Fagus sylvatica, Quercus petraea and Carpinus betulusand meadows which are generally mesophilic type.

In forming the soil cover in the northwest Cracau-Bistrita Depression a very important role was played by the climate, vegetation, topography, parent material and all local groundwater and water stagnation.

The main pedogenetic processes under the effect of environmental factors lead to the differentiation of horizons of soil and the formation and development of the soil cover of the northwest Cracau-Bistrita Depresion may be mentioned: bioaccumulation, clay migration, alteration, gleyzation and stagnogleyzation [7].

The assembly pedogenetic factors and processes led to the formation area on the ground floor of a relatively varied coating consisting of protisols, cernisols, cambisols, luvisols, hidrisols and antrisols (fig.10) [17, 33].

Protisols. Embedded soils in this class are not fully developed, young, emerging as ethnic aluviosols, eutric, gleyc, lithosols and rocks.

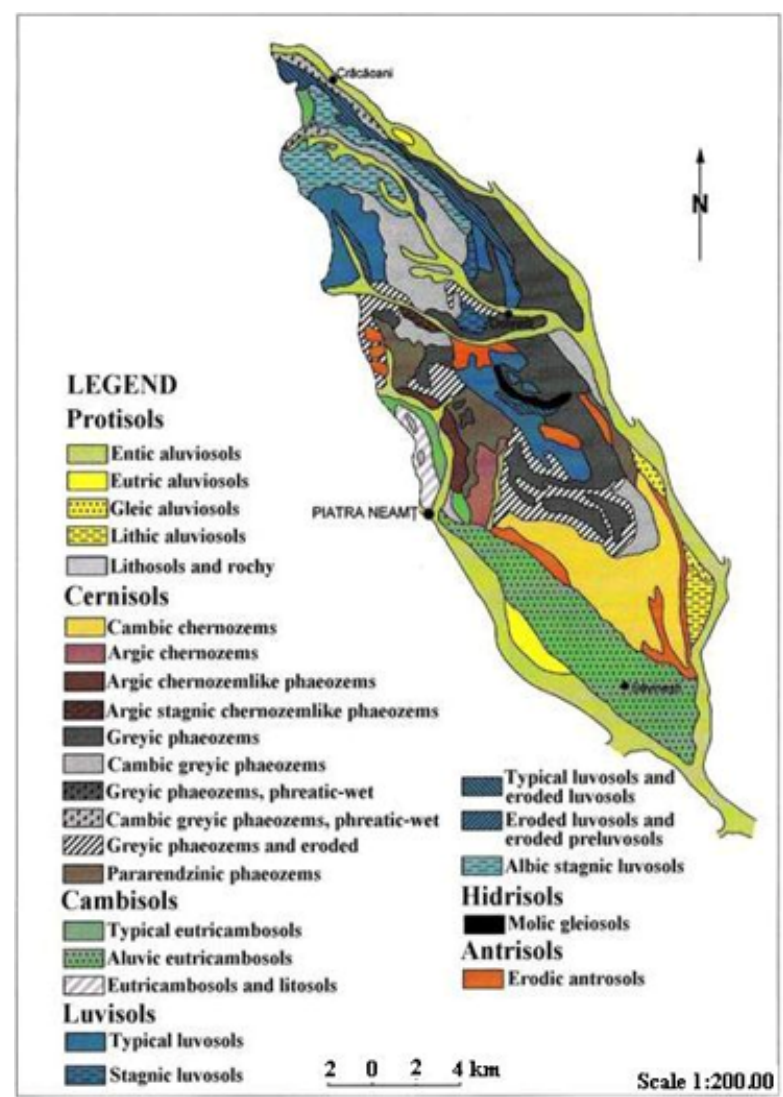

Fig. 10. Map soil of the northwest Cracau-Bistrita Depression [13]

Ethnic aluviosols are spread floodplain Cracau-Bistrita, as well as their main tributaries. Presents a varied texture from sandy to clay. The humus content rarely exceeds $1 \%$. In most enthic aluviosols have low fertility. They are used in the culture timber (Populus sp. and Salix sp.) and the crop (vegetable crops, pasture and hay) [34].

Lithic aluviosols appear local quite floodplain Cracau downstream from Caciulesti, notcultivated because of low depth which is gravel. Presents a profile of type $A o-A R-R$ moderately developed.

These soils are similar to those distric, but the horizon R, frequently consisting of gravel, whose upper limitis between $20 \mathrm{~cm}$ and $50 \mathrm{~cm}$ depth (fig. 11).

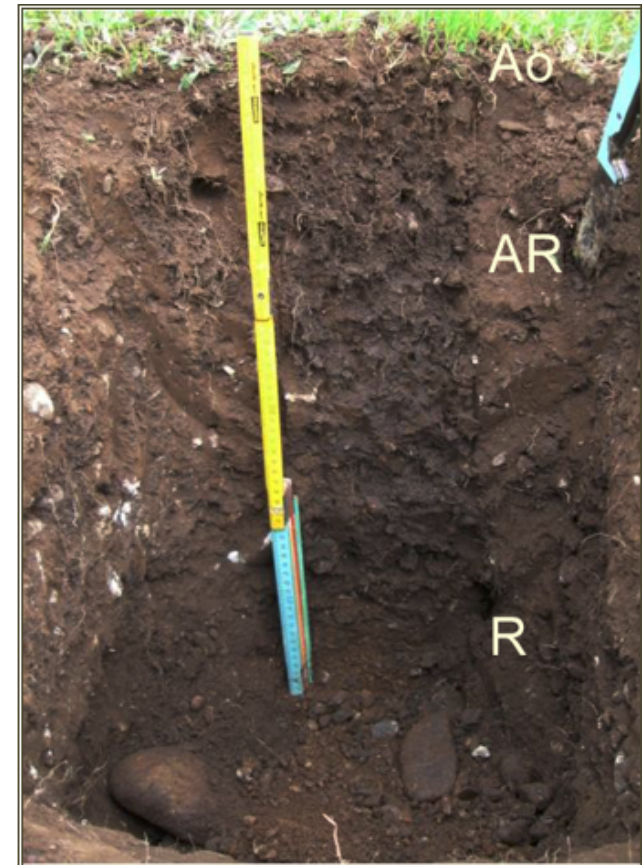

Fig. 11. Lithic aluviosols on the lower terrace of Bistrita in Dumbrava Rosie (Stanila, 2017) 
Cernisols are represented by cambic chernozems, argic chernozems, argic phaeozems, stagnic phaeozems, greiyc phaeozems, greiyc cambic phaeozems, including eroded and pseudorendzinas.

Cambic chernozems only on the spread confluence terrace Cracau-Bistrita of 35-40 m relative altitude on loesslike deposit.

Presents a profile of type $A m-A B-B v-C c a$ developed. Have a texture loam-clay-loam, clay content $<0.002 \mathrm{~mm}$ is between $26-36 \%$ in horizon Am and can climb to $40 \%$ in $A B$ and Bv horizons (table 1). The bulk density shows values that exceed $1.40 \mathrm{~g} / \mathrm{cm}^{3}$ and the total porosity of $46-56 \%$ reach values. Regarding withering coefficient rarely exceeds $11 \%$, the field capacity capacity ranges between $25-32 \%$ and useful water capacity it has values of 13 to $21 \%$. Their good permeability ranging from 10 to $21 \mathrm{~mm} / \mathrm{h}$.

Generally cambic chernozems the reaction have slightly acidic $\mathrm{pH}$ (6.3 to 6.8) and a low humus content (2.4-3.0\%). The bases are saturated ( $85-100 \%)$ and has a good supply of nutrients (N, 179\%; P, 28 ppm; K, 98 ppm) (table 2) [5].

They can be used especially in agriculture. Good results give the culture of wheat, barley, maize and sugar beet.

Argic chernozems are widespread in the southern half of the territory north of Piatra Neamt within certain heights interfluvial relatively flat and fairly well drained.

It is characterized by a profile of type $A m-A B-B t-C c a$ approx developed. Argic chernozem soils are differentiated texture profile as a result of migration clay. The surface of the humus content is $2.6-3.1 \%$ and decreases in the profile. For the supply of nutrients, it shows poor nitrogen, phosphorus and very good potassium.

Argic chernozem soil fertility fall into the category of medium, the cultivation of cereals (wheat and maize), oil plants (sunflower) and legumes (alfalfa and clover). Only associated with the use of the mineral organic fertilizer nitrogen and phosphorus could improve the fertility of these soils.

Argic chernozemlike phaeozems were formed under a cooler and wetter climate specific forest area. Appear terrace Cuejdiu. Presents a profile of type $A m-A B-B t-C c a$ moderate developed. They have a texture loam-clay (20-
$32 \%$ clay horizon surface). Contain from 3.5-5\% humus, maintaining more than $1 \%$ below the depth of 100 $\mathrm{cm}$. They are supplied with nutrient medium.

Argic chernozemlike phaeozems have a high potential fertility due to high humus content, and relatively favorable physical properties. Used with good results for both grain and for industrial plants.

Pseudorendzinas meet on large surfaces just north of Piatra Neamt, in terms of inter-grown hills or meadows and in the forest. Were formed on marly clay, marly.

Luvisols are represented by preluvosols and luvosols, the last with a wide range of subtypes: typical, albic, stagnic and eroded.

The typical luvosols appear in the upper basin of the Almas Valley, northwest of the town of the same name, in the hills north of Dobreni, between Sarata and Gura Vaii.

Typical luvosols presents a profile type: Ao-Elv-EB-Bt-C developed. Textured sandy loam in horizon Ao ( $22.7 \%$ clay) and gets clay loam in horizon B argic ( $40.4 \%$ clay).

The bulk density shows values that exceed $1.50 \mathrm{~g} / \mathrm{cm}^{3}$ and the total porosity of $10-24 \%$ reach values. Regarding withering coefficient rarely exceeds $28 \%$, the field capacity ranges between $7-15 \%$ and useful water capacity it has values of 7 to $17 \%$. The permeability shows a value between 0.2 to $4 \mathrm{~mm} / \mathrm{h}$ (table 3 ).

Generally typical luvosols the reaction have slightly acidic $\mathrm{pH}$ (5.8 to 5.9) and a low humus content (1.3 to $2.5 \%$ ).

The base saturation degree have values $78 \%$ within the horizon Ao. The supply of nutrients is not satisfactory in terms of nitrogen (100-110\%) and potassium (100-110 $\mathrm{ppm})$, but the means (20-36 ppm) in terms of phosphorus (table 4).

Albic stagnic luvosols are spread the northern half of the territory, occupying large areas on peaks higher interfluvial Cracau-Horaita Valleys between Almas.

Presents a profile type: Ao-Eaw-EBw-Btw-Bt-C.

Has a differentiated profile texture: sandy-loam in horizon Ao and Ea, but the profile is medium-fine.

Under forestexhibithigh humus content (10-18\%), while in the culture was roughly $2 \%$. The nutrients presentmodest values.

Table 1

PHYSICAL AND HYDRO-PHYSICAL DATA ON CAMBIC CHERNOZEMS

\begin{tabular}{|c|c|c|c|c|c|c|c|c|c|c|c|c|}
\hline \multirow[t]{2}{*}{ Horizon } & \multirow{2}{*}{$\begin{array}{l}\text { Depth } \\
\text { (cm) }\end{array}$} & \multicolumn{4}{|c|}{ Granulometric composition } & \multicolumn{7}{|c|}{ Physical and hydro-physical properties } \\
\hline & & $\begin{array}{c}<0,002 \\
\mathrm{~mm}\end{array}$ & $\begin{array}{c}0,002- \\
0,02 \mathrm{~mm}\end{array}$ & $\begin{array}{c}0,02- \\
0,2 \\
\mathrm{~mm}\end{array}$ & $\begin{array}{c}0,2-2 \\
\mathrm{~mm}\end{array}$ & $\underset{\mathrm{g} / \mathrm{cm}^{3}}{\mathrm{DA}}$ & $\begin{array}{l}\text { PT } \\
\%\end{array}$ & $\begin{array}{l}\mathrm{CO} \\
\%\end{array}$ & $\begin{array}{l}C C \\
\%\end{array}$ & $\begin{array}{l}\mathrm{CU} \\
\%\end{array}$ & $\begin{array}{l}\text { CT } \\
\%\end{array}$ & $\underset{\mathrm{mm} / \mathrm{h}}{\mathrm{K}}$ \\
\hline Ap & $0-17$ & 38.8 & 33.1 & 28.1 & 0.0 & 1.19 & 56 & 12 & 32 & 20 & 47.1 & 98.0 \\
\hline Aph & $17-30$ & 37.8 & 34.2 & 28.0 & 0.0 & 1.40 & 48 & 11 & 26 & 15 & 34.3 & - \\
\hline $\mathrm{Am}$ & $30-45$ & 40.0 & 33.8 & 36.2 & 0.0 & 1.41 & 48 & 11 & 25 & 14 & 34.0 & - \\
\hline $\mathrm{AB}$ & $45-62$ & 39.0 & 32.1 & 28.1 & 0.0 & 1.44 & 46 & 11 & 25 & 14 & 32.0 & - \\
\hline $\mathrm{Bv}_{1}$ & $62-82$ & 37.7 & 32.5 & 29.8 & 0.0 & 1.44 & 46 & 10 & 24 & 14 & 32.0 & - \\
\hline $\mathrm{Bv}_{2}$ & $82-112$ & 37.3 & 35.0 & 29.7 & 0.0 & 1.44 & 46 & 9 & 24 & 14 & 32.0 & - \\
\hline $\mathrm{Bv}_{3}$ & $112-140$ & 32.8 & 35.0 & 32.2 & 0.0 & 1.44 & 46 & 9 & 24 & 15 & 32.0 & - \\
\hline $\mathrm{Cca}$ & $140-170$ & 32.3 & 33.2 & 34.5 & 0.0 & 1.36 & 51 & 9 & 27 & 18 & 37.5 & - \\
\hline
\end{tabular}

Table 2

CHEMICAL DATA ON CAMBIC CHERNOZEMS

\begin{tabular}{|c|c|c|c|c|c|c|c|c|c|}
\hline Horizon & $\begin{array}{l}\text { Depth } \\
\text { (cm) }\end{array}$ & $\begin{array}{c}\mathrm{pH} \\
\left(\mathrm{H}_{2} \mathrm{O}\right)\end{array}$ & $\underset{\%}{\text { Humus }}$ & $\begin{array}{c}\text { SB } \\
\mathrm{me} / 100 \\
\mathrm{~g} \mathrm{sol}\end{array}$ & $\begin{array}{c}\mathrm{T} \text { me/l00 } \\
\mathrm{g} \mathrm{sol}\end{array}$ & $\begin{array}{l}V \\
\%\end{array}$ & $\begin{array}{l}\mathrm{Nt} \\
\%\end{array}$ & $\begin{array}{c}\mathrm{P} \\
\mathrm{Ppm}\end{array}$ & $\begin{array}{c}\mathrm{K} \\
\mathrm{ppm}\end{array}$ \\
\hline Ap & $0-17$ & 6.3 & 3.0 & 18.8 & 21.1 & 89.1 & 0.179 & 28 & 98 \\
\hline Aph & $17-30$ & 6.5 & 3.0 & 18.9 & 21.3 & 88.7 & 0.169 & 14 & 87 \\
\hline $\mathrm{Am}$ & $30-45$ & 6.8 & 2.4 & 19.4 & 20.5 & 85.1 & 0.154 & 3 & 108 \\
\hline$A B$ & $45-62$ & 7.2 & 2.1 & 19.7 & 21.1 & 93.4 & 0.138 & 3 & 108 \\
\hline Bv1 & $62-82$ & 7.2 & 1.9 & 19.2 & 20.0 & 96.0 & - & - & - \\
\hline $\mathrm{Bv}_{2}$ & $82-112$ & 7.2 & 1.2 & 18.1 & 18.8 & 96.3 & - & - & - \\
\hline $\mathrm{Bv}_{3}$ & $112-140$ & 7.4 & 0.9 & 17.4 & 18.8 & 97.6 & - & - & - \\
\hline $\mathrm{Cca}$ & $140-170$ & 8.1 & 0.8 & 14.7 & 17.8 & 100.0 & - & - & - \\
\hline
\end{tabular}

REV.CHIM.(Bucharest) $\$ 70 \diamond$ No. 4 \$ 2019

http://www.revistadechimie.ro 
Table 3

PHYSICAL AND HYDRO-PHYSICAL DATA ON TYPICAL LUVOSOLS

\begin{tabular}{|c|c|c|c|c|c|c|c|c|c|c|c|c|}
\hline \multirow[t]{2}{*}{ Horizon } & \multirow{2}{*}{$\begin{array}{l}\text { Depth } \\
\text { (cm) }\end{array}$} & \multicolumn{4}{|c|}{ Granulometric composition } & \multicolumn{7}{|c|}{ Physical and hydro-physical properties } \\
\hline & & $<0,002 \mathrm{~mm}$ & $\begin{array}{c}0,002-0,02 \\
\mathrm{~mm}\end{array}$ & $\begin{array}{c}0,02-0,2 \\
\mathrm{~mm}\end{array}$ & $\begin{array}{c}0,2-2 \\
\mathrm{~mm}\end{array}$ & $\begin{array}{c}\mathrm{DA} \\
\mathrm{g} / \mathrm{cm}^{3}\end{array}$ & $\begin{array}{r}\text { PT } \\
\%\end{array}$ & $\begin{array}{r}\mathrm{CO} \\
\%\end{array}$ & $\begin{array}{l}\mathrm{CC} \\
\%\end{array}$ & $\begin{array}{l}\mathrm{CU} \\
\%\end{array}$ & $\begin{array}{l}\text { CT } \\
\%\end{array}$ & $\mathrm{~K} \mathbf{m m} / \mathrm{h}$ \\
\hline Ao & $0-20$ & 22.7 & 35.5 & 41.3 & 2.5 & 1.46 & 10 & 23.0 & 15.3 & 7.7 & 30.2 & 4.0 \\
\hline Elv & $25-37$ & 25.2 & 35.0 & 40.4 & 6.4 & 1.45 & 11 & 23.0 & 14.3 & 8.7 & 22.6 & 2.0 \\
\hline EB & $40-52$ & 30.4 & 30.1 & 33.4 & 6.1 & 1.50 & 12 & 24.0 & 11.4 & 12.6 & 25.2 & 1.0 \\
\hline $\mathrm{Bt}_{1}$ & $53-79$ & 40.4 & 28.4 & 29.7 & 1.5 & 1.65 & 18 & 26.0 & 7.7 & 18.3 & 28.0 & 0.2 \\
\hline $\mathrm{Bt}_{2}$ & $79-106$ & 43.7 & 25.6 & 29.0 & 1.7 & 1.56 & 17 & 28.0 & 11.0 & 17.0 & 28.0 & 0.2 \\
\hline $\mathrm{Bt}_{3}$ & $106-131$ & 379 & 29.4 & 30.9 & 1.8 & 1.58 & 18 & 27.0 & 10.5 & 16.5 & 24.0 & 0.3 \\
\hline $\mathrm{Bt}_{4}$ & $131-200$ & 37.3 & 28.8 & 28.8 & 2.0 & 1.69 & 24 & 26.0 & 10.3 & 15.7 & 23.4 & 0.2 \\
\hline
\end{tabular}

Table 4

CHEMICAL DATA ON TYPICAL LUVOSOLS

\begin{tabular}{|c|c|c|c|c|c|c|c|c|c|}
\hline Horizon & $\begin{array}{l}\text { Depth } \\
\text { (cm) }\end{array}$ & $c \underset{\left(\mathrm{H}_{2} \mathrm{O}\right)}{\mathrm{pH}}$ & $\begin{array}{c}\text { Humus } \\
\%\end{array}$ & $\mathrm{C} / \mathrm{N}$ & $\begin{array}{c}\mathrm{T} \mathrm{me} / 100 \\
\mathrm{~g} \mathrm{sol}\end{array}$ & $\begin{array}{l}V \\
\%\end{array}$ & $\begin{array}{l}\mathrm{Nt} \\
\%\end{array}$ & $\begin{array}{c}\mathrm{P} \\
\mathrm{ppm}\end{array}$ & $\begin{array}{c}\mathrm{K} \\
\mathrm{ppm}\end{array}$ \\
\hline Ao & $0-20$ & 5.9 & 2.0 & 12.1 & 15.8 & 78.3 & 0.109 & 36 & 102 \\
\hline Elv & $25-37$ & 5.6 & 1.3 & 11.0 & 15.4 & 70.2 & 0.078 & 10 & 100 \\
\hline EB & $40-52$ & 6.5 & 1.0 & 10.1 & 20.6 & 71.5 & 0.064 & - & - \\
\hline $\mathrm{Bt}_{1}$ & $53-79$ & 6.4 & 0.5 & - & 27.1 & 84.4 & - & - & - \\
\hline $\mathrm{Bt}_{2}$ & $79-106$ & 6.6 & - & - & - & 85.2 & - & - & - \\
\hline $\mathrm{Bt}_{3}$ & $106-131$ & 6.8 & - & - & - & - & - & - & - \\
\hline $\mathrm{Bt}_{4}$ & $131-200$ & 7.0 & - & - & - & - & - & - & - \\
\hline
\end{tabular}

Cambisols are represented by typical eutricambosols, gravel shallow, and in association with lithosols.

Typical eutricambosols appear right Cuejdiu Valley north of Piatra Neamt under a hilly peaks rounded and extend the parent materials clay, carbonate weak nature delluvial.

Presents a profile of type $A 0-A B-B v-C c a$ moderatelydeeply developed.

They are covered forest, butare also used for agricultural purposes, it is planted with maize, potatoes, vegetables and fruit trees.

Eutricambosols on river gravel deposits at shallow meet only 2-4 terraces of Bistrita downstream of Piatra Neamt, under a relatively flat relief to parent materials such as alluvial, fine gravel made of rolled material mixed with medium fine, clay loam.

These soils are predominantly skeletal, high permeability.

It has a slightly acidic-neutral reaction, they are poor in humus and nutrients and low fertility. Currently used mainly for grazing.

Eutricambosols and lithosols

The presence of complex soils in this area is due to the non-uniformity of both the relief and the parent material.

Identified continuing typical eutricambosols, right Cuejdiu Valley under a slightly steep hilly slopes, mostly wooded.

Hidrisols. Included in this class are those soils that were formed and evolve under conditions of excess moisture coming from the ground water permanently. In the territory they are represented only by mollic gleiosols on alluvial deposits.

Appear scattered along a valley, whose origin is Hill Balaurului, beneath which is outlined, moving through Popesti to get to confluency with Cracau.

Alluvial parent material is likely, the water table is situated at a depth between 0.5-1.0 m.

In forming gleiosols contributed gleyzation caused by excessive groundwater wetting and bioaccumulation.

Presents a profile of type: Am-AGox-Gr. The texture of these soils is dominated clay loam.

They have a high humus content (5-10\%), pH reaction a neutral-weakly alkaline.

Because of their regime aerohidric poor and low microbiological activity, fertilising elements are hardly mobilized, so that their culture is rather difficultagricultural plants. Currently we are successfully used for pasture.

\section{Conclusions}

Local especially in the central and southern territory, land suitability is limited by certain factors, for which the areas under cereal plants, in some crops (maize, barley, sunflowers) inadequate low yields are obtained compared with the surrounding areas [35].

Some restrictive factors of agricultural production can be considered the soil, relief and the drainage.

\section{Soil factors}

The composition of predominantly fine particle size (clay loam) both in the upper horizon and the profile, and determining the textural differentiation in other cases a too high soil moisture, a satisfactory aeration.

The settlement is part of a restriction that comes with texture to enhance limitations. Of great importance in achieving good results must be considered reserve humus production. Erosion occurs as a limiting factor in terms inclined slope relief and significantly reduce agricultural production (fig. 12).

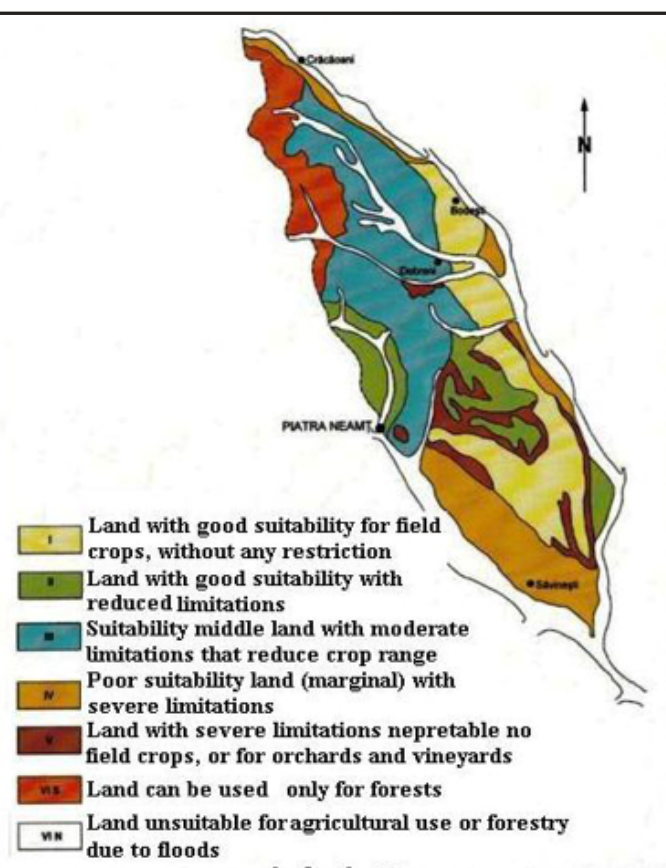

$\begin{array}{llll}2 & 0 & 2 & 4 \mathrm{Km}\end{array}$

Scale 1:200.000

Fig. 12. Map group on the use of arable land after the suitability of the northwest Cracau-Bistrita Depression (Stanila et al., 2017) [13] 


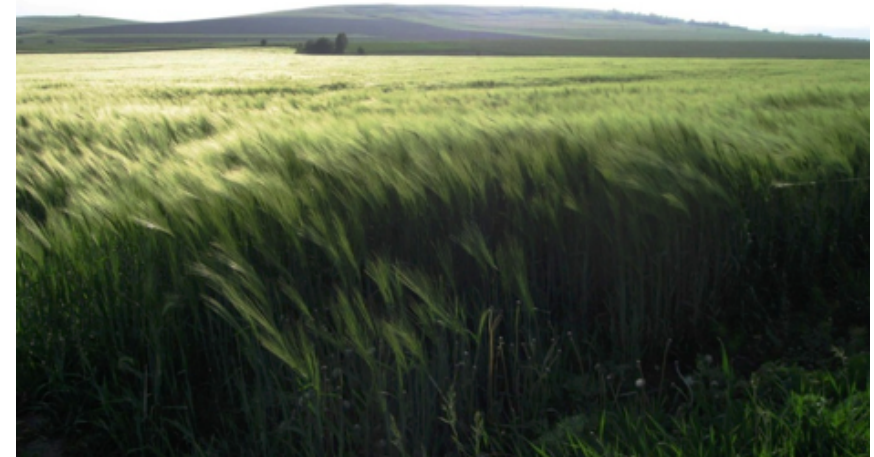

Fig. 13. Barley crop on the upper terrace of Cracau at Girov

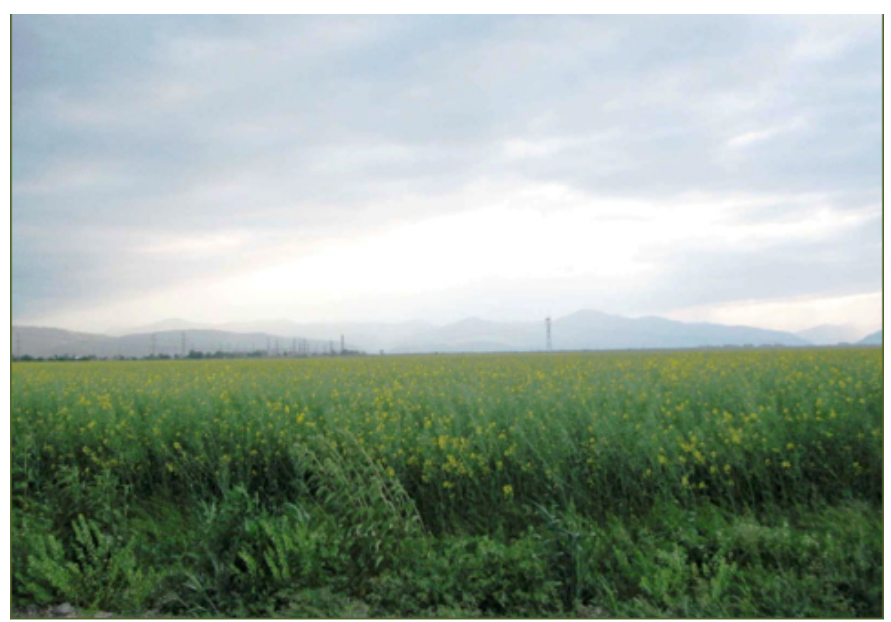

Fig. 14. Rape culture at Dochia

\section{Relief factor}

This limited arable land suitability by its unevenness, an exhibition of land and steepness, the intensity of the current geomorphological processes.

\section{Drainage factor}

Depending on the nature and intensity of production factors have particularly restrictive for the following categories of suitability to agricultural use:

- Class I - land with good suitability for field crops, without any restriction. It refers to the part of the terraces Bistrita and Cracau (fig.13, 14).

- Class II - land with good suitability with reduced limitations; the deficiencies can be addressed by damming Cracau.

- Class III- suitability middle land with moderate limitations that reduce crop range; to prevent degradation special investments are needed.

- Class IV - poor suitability land (marginal) with severe limitations (low edaphic volume, gravel shallow, surface erosion) that causes an appreciable reduction in the yields systematic, require special measures.

- Class V - land with severe limitations nepretabile no field crops, or for orchards and vineyards.

- Class VI - the lands can be used only for forests.

- Class VII - Land unsuitable for agricultural use or forestry due to floods.

In order to eliminate the negative effects of the limiting factors of agricultural production, reducing risks and improving the productive potential of the territory studied, we propose the following range of works:

- regulation of water flow;

- slight embankment works;

- erosion control works and avoid prolonged grazing early spring or autumn;
- the work on the contour land cultivation and hoeing plants avoid the slopes;

- works by scarification or compacted land affected by the excess moisture;

- skeletal material removal from the surface, the organomineral fertilizer radical.

Acknowledgement: We are very thankful to Department research in soil science, agrochemical and environmental protection, Laboratory of soil sciences and sustainable development for providing the necessary facilities to carry out this work through project PN 160701 09, Contract No. $16 \mathrm{~N} / 2016$.

\section{References}

1. APOSTOL, L., APAVALOAIE, M., LUPASCU, GH., Considerations on the air temperature Cracau-Bistrita Depression, Geographic Seminar "Dimitrie Cantemir", No.8, lasi, 1988.

2. BACAUANU, V., BARBU, N., PANTAZICA, MARIA, UNGUREANU, AL., CHIRIAC, D., Moldavian Plateau, Scientific and Encyclopedic Publishing, Bucharest, 1980.

3. BADEA, L., BUGA, D., BACAUANU, V., BERINDEI, I., CIOACA, A., ERDELI, G., NEAMU, GH., SANDU, M., VLAD, SORINA, ZAVOIANU, I., Geography of Romania, Volume IV, Romanian Academy Press, 1992. 4. BOJOI, I., Problem formation gorge Cuejdiu-Piatra Neamt about a disheveled phenomenon of Bistrita, Work Station Oak, GeologyGeography Pangarati, 1972.

5. BORLAN, Z., RAUTA, C., Agrochemical soil analysis methodology in order to establish the necessary amendments and fertilizers, ICPA, Bucharest, 1981.

6. CANARACHE, A., Soil physics, Ceres Publishing House, Bucharest, 1990, p.268.

7. CERNESCU, N., Facteurs de climat et zones de sol en Roumanie, Geological Institute of Romania, Technical and economic studies, Series C, No. 2, Bucharest, 1934.

8. CONEA, ANA, VINTILA, IRINA, CANARACHE, A., Dictionary of soil science, Scientific and Encyclopedic Publishing, Bucharest, 1977, p. 671.

9. DONISA, I., Contributions to the geomorphological study of the Bistrita, Scientific Annals University lasi, Vol.VI, Section II, Iasi, 1960. 10. DONISA, I., POGHIRC, P., Bistrita Valley, Publishing Scientific, Bucharest, 1968.

11. DONISA, I., Geomorphology Bistrita, Academy Press R.S.R., Bucharest, 1968.

12. ENCULESCU, P., Research general agrogeology in NV Moldova, Report on the work of courts, Geological Institute of Romania, Bucharest, 1914.

13. FLOREA, N., PARICHI, M., VESPREMEANU, R., BARBU, N., LUPASCU, GH., RUSU, C., Soil Map of Romania, Piatra Neamt, Sheet, Sc.1:200,000, ICPA, Bucharest, 1990.

14. FLOREA, N., MUNTEANU, I., RUSU, C., DUMITRU, M., IANOS, GH., RADUCU, DANIELA, ROGOBETE, GH., TARAU, D., Romanian System of Soil Taxonomy, Sitech Publishing House, Bucharest, 2012, p. 206. 15. FRASINEANU, MIHAELA, Romanian Rivers, Romania for Tomorrow Publishing House, Bucharest, 2008, p.187.

16.ICHIM, I., Stanisoara Mountains, Geomorphological study, Publishing Academy, Bucharest, 1979.

17. ISPAS, ST., STANILA, ANCA-LUIZA, Romanian soils, Publisher Valahia University Press, Targoviste, 2015, p. 246.

18. LUPASCU, GH., RUSU, C., Research on the productive capacity of land Cracau-Bistrita Depression, Geographical works Dimitrie Cantemir, No. 11, lasi, 1991.

19.LUPASCU, GH., Cracau-Bistrita Depresion-Study pedoge ographic, Publisher Corson, Iasi, 1996.

20. LUPASCU, GH., PARICHI, M., STANILA, ANCA-LUIZA, FLOREA, N., References pedological Romania, Terra Nostra Publishing House, lasi, 2003, p. 637. 
21.OBREJ EANU, GR., Agropedologic study of the experimental stations of I.C.A.R., Bucharest, Romanian Academy Publishing House, Bucharest, 1958, p.152.

22. PARICHI, M., STANILA, ANCA-LUIZA, STAICU, FILUTA, MOISE, IRINA, Contributions to the knowledge of soils of low Hills Tutovei, Annals of Spiru Haret University, Geography Series, No. 1, Romania for Tomorrow Publishing House, Bucharest, 1998, p. 33-38.

23. PARICHI, M., STANILA, ANCA-LUIZA, CRUCERU, N., Soils main relief units in Romania, Romania for Tomorrow Publishing House, Bucharest, 2006, p.179.

24. PARICHI, M., Erosion and soils erosion, Romania for Tomorrow Publishing House, Bucharest, 2007, p.102.

25. PARICHI, M., STANILA, ANCA-LUIZA, Pedological soil and land evaluation, Soil risks., Romania for Tomorrow Publishing House, 2008, p.110.

26. POSEA, GR., POPESCU, N., IELENICZ, M., Romania's relief, Scientific Publishing, Bucharest, 1974.

27. POSEA, GR., BADEA, L., Regionalization geomorphological, Scientific and Encyclopedic Publishing, Bucharest, 1984.

28. POSEA, GR., CRUCERU, N., Geomorphology Romania, Romania for Tomorrow Publishing House, Bucharest, 2005, p.364.

29. RUSU, C., MARGARINT, M.C., RUSU, E., Observations on recent dynamics of river basin relief Cuiejdel, Mountains Stanisoarei, Implications for Cross Lake Hydrogeomorphic complex, Magazine Geomorphology, Corint Publishing, Bucharest, 2002.

30. RUSU, C., STANGA, I.C., Considérations sur le relief fluvial du bassin montagneux de Cracau, Annals of Al. I. Cuza lasi, Geography Series, 2004, p. 28-32.
31. STANILA, ANCA-LUIZA, PARICHI, M., Soils mapping, Romania for Tomorrow Publishing House, Bucharest, 2001, p.160.

32. STANILA, ANCA-LUIZA, PARICHI, M., Glossary of soil science, Romania for Tomorrow Publishing House, Bucharest, 2005, p. 108.

33. STANILA, ANCA-LUIZA, PARICHI, M., What you need to know about the soil they work, Romania for Tomorrow Publishing House, Bucharest, 2012, p.72.

34. STANILA, ANCA-LUIZA, DUMITRU, M., SIMOTA, C., Contributions to the knowledge of soil resources of Cuca Plain, J ournal of Agricultural Studies, Vol. 5, No.2, 2017, p. 13-31.

35. STANILA, ANCA-LUIZA, SIMOTA, C., DUMITRU, M., Research on the Presence Greyic Phaeozems in Romania, J ournal of Agricultural Studies, Vol. 5, No.3, 2017, p.75-87.

36. STOICA, ELENA, RAUTA, C., FLOREA, N., Methods for chemical analysis of soil, ICPA, Bucharest, 1986, p. 487.

37. SURDEANU, V., Geography degraded land-slides, Cluj University Press, Cluj.

38. VELCEA, VALERIA, SAVU, Al., Geography Carpathians and Subcarpathians Romanian, Didactic and Pedagogic Publishing, Bucharest.

39. **** Development methodology soil studies (3 Volume), ICPA, Bucharest, 1987, p.726.

40. ***Romanian system of soil classification, ICPA, Bucharest, 1980. 41. ***Geological map of R.S.Romania, Scale 1:200.000, Sheet Piatra Neamt, Geological Institute of Romania, Bucharest, 1990.

Manuscript received: 21.05 .2018 